International Journal of Environment, Agriculture and Biotechnology
Vol-6, Issue-2; Mar-Apr, 2021
JESB
Journal Home Page Available: https://ijeab.com/
Journal DOI: $10.22161 /$ ijeab

\title{
The impact of China's fertilizer industry de-capacity on agricultural production costs
}

\author{
Yongxi Li, Yujian Wu
}

School of Finance and Taxation, Central University of Finance and Economics, 39 South College Road, Haidian District, Beijing, P.R.China

Received: 28 Dec 2020; Received in revised form: 19 Feb 2021; Accepted: 25 Mar 2021; Available online: 16 Apr 2021

(C)2021 The Author(s). Published by Infogain Publication. This is an open access article under the CC BY license

(https://creativecommons.org/licenses/by/4.0/).

\begin{abstract}
In response to the re-collection of value-added tax and the abolition of fiscal and tax preferential policies for the fertilizer industry in 2015, using provincial panel data from 2011 to 2018, a model was established to analyze the impact of policy changes on agricultural production costs. Research shows that after the implementation of the policy, agricultural intermediate consumption has increased significantly by $11 \%$, and the proportion of fertilizer fees in total costs has increased significantly by $0.5 \%$. It can be inferred that it has increased agricultural production costs, while the profitability of fertilizer companies has not changed significantly, Which proves that after the abolition of preferential fiscal and taxation policies for chemical fertilizers, at least part of the cost of enterprises has been transferred to farmers, which has increased the burden on farmers. Suggestions on the need to rationally guide the transformation and upgrading of fertilizer companies, formulate fertilizer subsidies for farmers, and actively promote reasonable fertilization.
\end{abstract}

Keywords—Fiscal and tax policy, fertilizer, agricultural production cost, VAT

\section{INTRODUCTION}

Fertilizers play an irreplaceable role in modern agricultural production. Under the impact of the 2020 locust plague and the COVID-19 epidemic, world food production has generally decreased and many countries have announced restrictions on food exports, posing new challenges to China's food security. Fertilizers have a significant role in increasing food production, but the continuous expansion of fertilizer production capacity has led to greater pressure on enterprises to de-stock, and according to statistics, the problem of overcapacity in China's fertilizer industry was serious in 2015.In 2015, the Ministry of Finance, the Development and Reform Commission and other ministries issued successive notices on the reimposition of VAT on fertilizers and the cancellation of some preferential fiscal policies, and the former Ministry of Agriculture formulated the Action Plan for Zero Growth in Fertilizer Use by 2020 The Programme pointed out the problems of blind fertiliser application, low utilisation of organic fertiliser resources and unbalanced fertiliser application structure in China, requiring zero growth in fertiliser use by 2020. While these policies are guiding the fertiliser industry to remove production capacity, reduce fertiliser waste and reduce environmental pollution, it is worth exploring whether enterprises are transferring the new costs brought about by the removal of preferential policies to farmers who are in a disadvantaged position, thus leading to an increased burden on farmers.

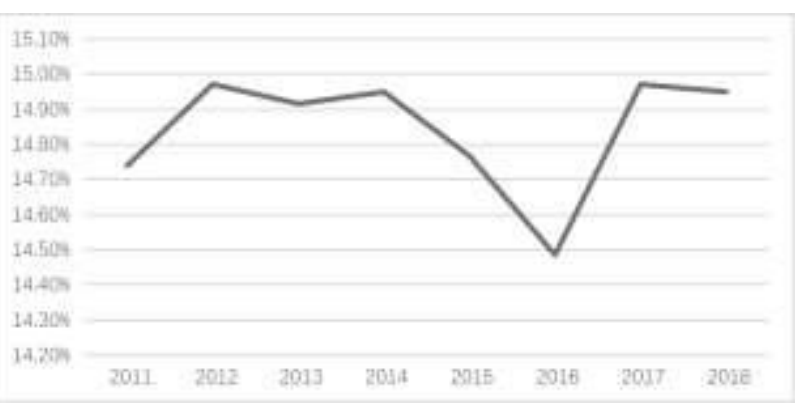

Fig. 1: Fertilizer consumption in China as a proportion of total agricultural output (Data source: China Rural Statistical Yearbook) 


\section{REVIEW OF THE LITERATURE}

In the field of agriculture, fiscal and taxation policies have an important regulatory role. Bo Li et al (2019) summarize the content of agricultural fiscal and taxation policies into three main categories: fiscal agricultural subsidy policies, fiscal agricultural investment policies, and agriculturalrelated taxation policies. Among them, agricultural subsidy policy is the most commonly used policy in agricultural policy, which is more flexible and can target specific groups or be oriented to the general farmers. Xiangdong Yang (2016) found that China's agriculture-related tax policies are not perfect, and the preferential policies for agriculture-related taxes are convenient and single, mainly focusing on income, however, there are fewer preferences in terms of transfer. At the same time, tax concessions are mainly for high-quality agricultural products assessed as provincial and national level, and the concessions for basic agricultural construction are low. Although VAT is a more excellent tax, there are limitations in the operation of VAT in agriculture, and the current VAT is not strong enough to protect agricultural products and industrialized operations, and the VAT rate for processing industries is obviously high, which is not conducive to the development of agricultural industrialization. China has previously implemented preferential fiscal policies for the fertilizer industry for a long time, and Ke Feng (2015) argues that China's fertilizer industry was not yet mature enough to meet the needs of agricultural modernization in the 1990s, and that the actual proof of preferential fiscal policies for the fertilizer industry has promoted the rapid expansion of the fertilizer industry, which is conducive to safeguarding China's fertilizer supply and stabilizing food prices. After years of development, China's fertilizer industry is facing backward technology and overcapacity. It is imperative to abolish preferential fiscal policies and promote the market to play a decisive role in the allocation of resources in the fertilizer industry. Keqing Zhou et al (2019) summarised and reviewed the changes in China's preferential fiscal policies for fertilisers. With the development of economy and society, some traditional unreasonable fiscal and tax policies have not adapted to the upgrading of China's industrial structure and changes in the market environment. Faced with factors such as overcapacity, the reintroduction of VAT on fertilizers did not necessarily bring about an increase in the final price of fertilizers. Yong Fan et al (2020) found that the direction of the impact of VAT on final product prices depends on the direction of tax burden shifting. Tao Wen (2011) explored the impact of fiscal policy on agriculture and found that the effect of active fiscal policy in agriculture on food price volatility is significant. Su Chen (2017) explored and found that agricultural policy adjustments since 1994 can affect the incentive of farmers to grow food.

Objectively, the use of chemical fertilizers has promoted increased food production, and in modern society chemical fertilizers are widely used in the growth stages of all types of food crops. Jikun Huang et al (1994) studied the effect of chemical fertilizers on rice crops and found that chemical fertilizers could significantly increase the yield per acre of rice, while labour inputs were found to have a limited effect on increasing rice yields. Lingling Yang (2018) noted that there were many wasted resources in agricultural production, especially the excessive use of chemical fertilizers. By constructing a model between fertilizer use and total agricultural output, the study found a "negative relationship" between fertilizer use and total agricultural output. Jun Yin et al (2020) analysed fertiliser and other factor input and price data from 2004 to 2016 and found that various price variables, such as fertiliser prices, labour prices and machinery prices, had a significant impact on the amount of fertiliser input in maize production. Yijie Deng (2019) conducted an empirical study on fertiliser application in Sichuan between 2001 and 2015 and concluded that changes in fertiliser use brought about positive changes in grain yield, while the elasticity of fertiliser application and grain yield increase showed an upward and then downward trend. Denglin Shi (2020) significantly increased soil organic carbon (SOC) content, soil microbial biomass carbon (MBC) and carbon readily available (ROC) content by reducing the amount of $\mathrm{N}$ fertilizer by $20 \%$ with a moderate amount of biochar, which could also increase rice yield.

In 1998, the State Council issued the "Notice of the State Council on Deepening the Reform of the Fertilizer Distribution System", which stipulated that the ex-factory price of fertilizer was changed from the previous government pricing to the government guiding price, but at the same time the fluctuation range of fertilizer prices was limited. 2009, the National Development and Reform Commission and the Ministry of Finance jointly issued the "Notice on Reforming the Fertilizer Price Formation Mechanism Notice", which adjusted the previous government-guided price to a market-regulated price. Zuli Wang et al (2011) found that fertiliser prices were mainly positively correlated with food prices, raw material prices and the supply-demand gap, and that the effect of national policies to limit fertiliser prices was not significant. Wenxiong Zhang et al (2014) showed that fertilizer price fluctuations have obvious clustering and long-term memory, and that fertilizer market price fluctuations are asymmetric, with fluctuations triggered by information on rising prices being greater than those triggered by 
information on falling prices. Ming Qin (2016) found that there is a long-run cointegration relationship between energy prices and fertilizer prices.

The cost of fertilizer is positively correlated with unit price and quantity. Jingxian Ru (2008) found that fertiliser application was mainly positively related to the education level of the household head, time spent in agricultural activities, attitude towards risk, and total household income of the farming household; and negatively related to trust channels, the farming household's perception of fertiliser utilisation, and the farming household's perception of pollution. Yinglu Bu et al (2020) concluded that fertiliser application was also correlated with factors such as whether farmers participated in technical guidance on fertiliser use, whether they frequently enquired about agricultural technology knowledge, acceptance of external fertiliser promotion and arable land area and household income.

At present, the academic community has rarely explored whether policy changes affect the cost of agricultural production from a fiscal perspective. As fertiliser is an important component of agricultural intermediate consumption, a change in tax incentives for fertiliser may affect the price of fertiliser and hence the cost of agricultural production. This paper therefore proposes the hypothesis that the removal of a series of fiscal support policies in the fertiliser industry will lead to an increase in the price of fertiliser and hence in the cost of agricultural production.

\section{DATA DESCRIPTION AND MODEL DESIGN}

In this paper, we first collated the fertilizer inputs of seven grain crops, including early indica rice, middle indica rice, late indica rice and japonica rice, and nine non-grain crops, including peanut, rapeseed, cotton and vegetables, from 2011 to 2018 in the National Compilation of Information on Costs and Benefits of Agricultural Products, and intuitively, the mean, median and extreme values of the average fertilizer per mu for grain crops and non-grain crops were different (Table 1). The t-test shows that the difference in mean fertiliser use per acre between food and non-food crops is statistically significant, with the mean fertiliser use per acre for non-food crops being significantly higher than that for food crops (Table 2). Therefore, theoretically, there is a difference between the policy change for food crops and non-food crops.

Table 1. Descriptive statistics of fertilizer use per mu in different crop categories

\begin{tabular}{|c|c|c|c|c|c|c|c|}
\hline 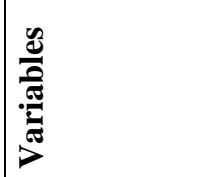 & 总 & 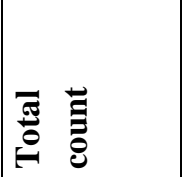 & 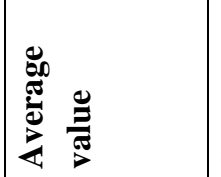 & 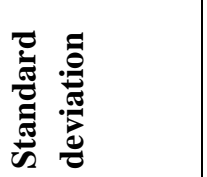 & 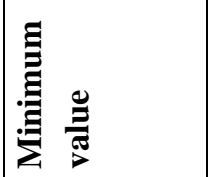 & 离 & 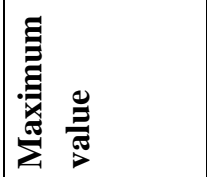 \\
\hline \multirow[t]{2}{*}{ Consumption } & Non-food & 72 & 3.5685 & 0.4519 & 2.6810 & 3.5931 & 4.2099 \\
\hline & Food & 56 & 2.9946 & 0.3594 & 2.1211 & 3.1219 & 3.3203 \\
\hline
\end{tabular}

Table 2. T-test for differences in mean discounted net fertilizer use per acre for different crop categories

\begin{tabular}{|c|c|c|c|}
\hline \multicolumn{4}{|c|}{$\mu_{1}$ : Mean value of Consumption (non-food) } \\
\hline \multicolumn{3}{|c|}{$\mu_{2}$ : Mean value of Consumption (food) } \\
\hline Difference: $\mu_{1}-\mu_{2}$ & Difference & 95\% confidence interval of the difference \\
\hline Original assumption $\mathrm{H}_{0}: \mu_{1}-\mu_{2}=0$ & 0.5739 & \multicolumn{3}{|c|}{$(0.4319,0.7158)$} \\
\hline Alternative hypothesis $\mathrm{H}_{1}: \mu_{1}-\mu_{2} \neq 0$ & T-value & Degree of freedom & P-value \\
\hline
\end{tabular}

This paper selects provincial administrative units in China from 2011 to 2018 as the sample for the study, excluding Hong Kong SAR, Macau SAR, Taiwan Province and four municipalities directly under the Central Government which lack statistical data, and the data are obtained from the China Labour Statistical Yearbook, the
China Statistical Yearbook, the China Rural Statistical Yearbook and the National Compilation of Information on Costs and Benefits of Agricultural Products. All data on financial resources were adjusted to comparable prices in 2011 using the Consumer Price Index for Rural Residents.

The regression model is as follows: 
Intermediate_consumption $_{\mathrm{i}, \mathrm{t}} \quad=\quad \alpha+\beta_{1}$ Policy $_{\mathrm{i}, \mathrm{t}}+\beta_{2}$ Chemical_fertilizer $_{\mathrm{i}, \mathrm{t}}+\beta_{3}$ Sown_area $_{\mathrm{i}, \mathrm{t}}+\beta_{4}$ Fuel $_{\mathrm{i}, \mathrm{t}}+\beta_{5}$ Electricity $_{\mathrm{i}, \mathrm{t}}+\beta_{6}$ Film $_{\mathrm{i}, \mathrm{t}}+\beta_{7}$ Pesticide $_{\mathrm{i}, \mathrm{t}}+\beta_{8}$ Mechanization $_{\mathrm{i}, \mathrm{t}}+\beta_{9}$ Wage $_{\mathrm{i}, \mathrm{t}}+\beta_{10}$ gap $_{\mathrm{i}, \mathrm{t}}+\beta_{11}$ Proportion_of_operating_income $_{\mathrm{i}, \mathrm{t}}$ $+\beta_{12}$ Population_quality $y_{i, t}+\mu_{\mathrm{t}}+\gamma_{\mathrm{i}}+\varepsilon_{\mathrm{i}, \mathrm{t}}$

Equation 1

where $\mathrm{i}$ and $\mathrm{t}$ denote province and time respectively, $\mu \mathrm{t}$ is the year fixed effect, $\gamma \mathrm{i}$ is the province fixed effect, and $\varepsilon i, t$ is the regression residual term. In this paper, the standard errors are clustered to the province level.

The explanatory variable Intermediate_consumptioni,t denotes the agricultural intermediate consumption in province $\mathrm{i}$ in year $\mathrm{t}$. Intermediate consumption is a component of total agricultural output and consists of material consumption and production service expenditures, and in 2018, fertilizer expenditures accounted for about $15 \%$ of the intermediate consumption in agriculture, forestry, animal husbandry and fisheries, and about $20 \%$ to $30 \%$ of the agricultural intermediate expenditures. In addition to fertiliser, intermediate consumption related to agricultural production includes the amount of seed used, fuel, pesticides, agricultural film, electricity and small farm machinery. The amount of seed used is controlled by the total sown area of the crop (Sown_area); since more than $70 \%$ of the power in agriculture is diesel, the amount of diesel used in agriculture is used to control fuel (Fuel). In addition, other influencing factors are controlled for, such as the gap between urban and rural incomes (gap), the proportion of operating income in the disposable income of rural residents (Proportion_of_operating_income), and the education level of the regional population (Population_quality). Since the policy has different effects on food cultivation and non-food cultivation, a total of thirteen major food-producing regions in China, namely Liaoning, Hebei, Shandong, Jilin, Inner Mongolia, Jiangxi, Hunan, Sichuan, Henan, Hubei, Jiangsu, Anhui and Heilongjiang, were set as the control group (Treat=0), and the remaining fourteen provincial units were set as the experimental group (Treat=1). The policy time was 2015, so non-major grain-producing provinces in 2015 and beyond $=1$ and others $=0$. Table 3 shows the variables and their definitions, and Table 4 reports descriptive statistics for the core variables.

Table 3. Model variables and variable definitions

\begin{tabular}{|l|l|}
\hline Variables & Variable definitions \\
\hline Policy & Non-food producing provinces in 2015 and beyond =1, others =0 \\
\hline Intermediate_consumption & Ln (agricultural intermediate consumption (adjusted to 2011)) \\
\hline Chemical_fertilizer & Ln (amount of fertilizer applied) \\
\hline Sown_area & Ln (total area sown to crops) \\
\hline Fuel & Ln (agricultural diesel use) \\
\hline Electricity & Ln (rural electricity consumption) \\
\hline Film & Ln (amount of agricultural plastic film used) \\
\hline Pesticide & Ln (pesticide use) \\
\hline Mechanization & Ln (total power of agricultural machinery) \\
\hline Wage & Ln (average wage of persons employed in agriculture in urban units (adjusted to 2011)) \\
\hline gap & $\begin{array}{l}\text { Comparison of income levels of disposable income between urban and rural residents (rural } \\
\text { residents = 1) }\end{array}$ \\
\hline $\begin{array}{l}\text { Proportion_of_operating_inc } \\
\text { ome }\end{array}$ & \begin{tabular}{l} 
Net operating income as a percentage of total revenue \\
\hline Population_quality
\end{tabular} \\
\hline
\end{tabular}




\begin{tabular}{|c|c|c|c|c|c|c|c|}
\hline Variables & Treat & $\begin{array}{l}\text { Total } \\
\text { count }\end{array}$ & \begin{tabular}{|l} 
Average \\
value
\end{tabular} & $\begin{array}{l}\text { Standard } \\
\text { deviation }\end{array}$ & \begin{tabular}{|l|} 
Minimum \\
value
\end{tabular} & Median & $\begin{array}{l}\text { Maximum } \\
\text { value }\end{array}$ \\
\hline \multirow[t]{2}{*}{ Intermediate_consumption } & 0 & 104 & 6.6734 & 0.4740 & 5.7239 & 6.7192 & 7.5474 \\
\hline & 1 & 112 & 5.676 & 1.060 & 2.833 & 6.016 & 6.993 \\
\hline \multirow[t]{2}{*}{ Chemical_fertilizer } & 0 & 104 & 5.6198 & 0.4211 & 4.8138 & 5.5278 & 6.5738 \\
\hline & 1 & 112 & 4.421 & 1.169 & 1.567 & 4.669 & 5.575 \\
\hline \multirow[t]{2}{*}{ Sown_area } & 0 & 104 & 9.0158 & 0.3323 & 8.3099 & 9.0573 & 9.6013 \\
\hline & 1 & 112 & 7.7931 & 0.9859 & 5.4866 & 8.2402 & 8.8811 \\
\hline \multirow[t]{2}{*}{ Fuel } & 0 & 104 & 4.3983 & 0.5836 & 3.2696 & 4.2959 & 5.6839 \\
\hline & 1 & 112 & 3.597 & 1.065 & 1.099 & 3.803 & 5.314 \\
\hline \multirow{2}{*}{ Electricity } & 0 & 104 & 5.2761 & 1.0006 & 3.7495 & 5.0518 & 7.5669 \\
\hline & 1 & 112 & 4.126 & 1.856 & -0.105 & 4.438 & 7.275 \\
\hline \multirow[t]{2}{*}{ Film } & 0 & 104 & 11.535 & 0.461 & 10.773 & 11.478 & 12.672 \\
\hline & 1 & 112 & 10.545 & 1.251 & 6.939 & 10.744 & 12.506 \\
\hline \multirow[t]{2}{*}{ Pesticide } & 0 & 104 & 11.320 & 0.433 & 10.105 & 11.344 & 12.013 \\
\hline & 1 & 112 & 9.918 & 1.439 & 6.828 & 10.343 & 11.645 \\
\hline \multirow[t]{2}{*}{ Mechanization } & 0 & 104 & 8.5106 & 0.5142 & 7.6079 & 8.4342 & 9.4995 \\
\hline & 1 & 112 & 7.3449 & 0.7150 & 6.0176 & 7.6820 & 8.2436 \\
\hline \multirow[t]{2}{*}{ Wage } & 0 & 104 & 10.174 & 0.365 & 9.348 & 10.198 & 10.971 \\
\hline & 1 & 112 & 10.333 & 0.327 & 9.450 & 10.351 & 11.004 \\
\hline \multirow[t]{2}{*}{ gap } & 0 & 104 & 2.4953 & 0.2360 & 2.0300 & 2.4700 & 3.0700 \\
\hline & 1 & 112 & 2.9694 & 0.4499 & 2.0400 & 2.9600 & 3.9800 \\
\hline \multirow[t]{2}{*}{ Proportion_of_operating_income } & 0 & 104 & 0.4551 & 0.1030 & 0.2890 & 0.4335 & 0.7250 \\
\hline & 1 & 112 & 0.4318 & 0.1146 & 0.2430 & 0.4320 & 0.7140 \\
\hline \multirow[t]{2}{*}{ Population_quality } & 0 & 104 & 0.04953 & 0.01637 & 0.02083 & 0.05029 & 0.08440 \\
\hline & 1 & 112 & 0.08842 & 0.08351 & 0.02379 & 0.06160 & 0.44388 \\
\hline
\end{tabular}

IV. EMPIRICAL RESULTS AND ANALYSIS OF RESULTS

4.1 Regression results

Table 5 shows the results of the benchmark regressions, which indicate that the policy significantly increased the amount of intermediate consumption in agriculture, i.e. raised the cost of agricultural production.

Table 5. Impact of policies on intermediate consumption in agriculture

\begin{tabular}{l|l}
\hline & (Equation 1$)$ \\
\hline VARIABLES & Intermediate_consumption \\
\hline Policy & $0.110 * *$
\end{tabular}

(2.39)

\begin{tabular}{l|l}
\hline Chemical_fertilizer & -0.050 \\
& $(-0.18)$ \\
\hline Sown_area & 0.443 \\
& $(1.52)$ \\
\hline Fuel & 0.015 \\
& $(0.18)$ \\
\hline Electricity & $0.540^{* *}$ \\
& $(2.41)$ \\
\hline Film & $-0.230^{*}$ \\
& $(-1.96)$ \\
\hline
\end{tabular}




\begin{tabular}{l|l}
\hline Pesticide & 0.064 \\
& $(0.43)$ \\
\hline Mechanization & 0.086 \\
& $(0.95)$ \\
\hline Wage & 0.023 \\
& $(0.22)$ \\
\hline gap & -0.073 \\
& $(-0.62)$ \\
\hline Proportion_of_operatin & 0.226 \\
g_income & \\
\hline Population_quality & $(0.82)$ \\
\hline Constant & -0.262 \\
& $(-0.40)$ \\
\hline Observations & 1.070 \\
\hline Number of Province & $(0.50)$ \\
\hline R-squared & 216 \\
\hline Province FE & 0.666 \\
\hline Year FE & YES \\
\hline \multicolumn{1}{c}{ Robust t-statistics in parentheses } \\
\hline
\end{tabular}

In order to further test the impact mechanism of the policy, a model was designed using the total cost per mu, fertiliser cost per mu and discounted fertiliser dosage per $\mathrm{mu}$ for various crops in each region from the National Compilation of Agricultural Cost and Benefit Information (Equation 2).

Proportion_of_fertilizer_cost $\mathrm{i}_{\mathrm{i}, \mathrm{s}, \mathrm{t}}=\alpha+\beta_{1}$ Policy $_{\mathrm{s}, \mathrm{t}}+\beta_{2}$ Consumption $_{\mathrm{s}, \mathrm{t}}+\mu_{\mathrm{t}}+\gamma_{\mathrm{i}}+\delta_{\mathrm{s}}+\varepsilon_{\mathrm{i}, \mathrm{s}, \mathrm{t}} \quad$ Equation 2

where $\mathrm{i}, \mathrm{s}$ and $\mathrm{t}$ denote province, crop species and time respectively, $\mu_{t}$ is the year fixed effect, $\gamma_{i}$ is the province fixed effect, $\delta_{\mathrm{s}}$ is the species fixed effect, and $\varepsilon_{\mathrm{i}, \mathrm{s}, \mathrm{t}}$ are the regression residual terms. proportion_of_fertilizer_cost is the proportion of fertilizer cost per acre to total cost per acre, Consumption is the discounted pure fertilizer per acre Table 6 shows the regression results, which show that the policy has a significant positive relationship with fertilizer cost per acre to total cost per acre. Combining the results of the Equation 1 test with the fact that intermediate consumption is an important component of total cost, it can be concluded that the policy has increased the intermediate consumption of agriculture by raising the fertilizer fee.

Table 6. Impact of policy on fertiliser charges as a proportion of costs

\begin{tabular}{l|l}
\hline VARIABLES & $\begin{array}{l}\text { (Equation 2) } \\
\text { Proportion_of_fertilizer_cost }\end{array}$ \\
\hline Policy & $\begin{array}{l}0.005^{* * *} \\
(3.44)\end{array}$ \\
\hline Consumption & $\begin{array}{l}0.051^{* * *} \\
(28.88)\end{array}$ \\
\hline Constant & $-0.030^{* * *}$ \\
& $(-5.26)$ \\
\hline Observations & 3,636 \\
\hline R-squared & 0.720 \\
\hline Province FE & YES \\
\hline Year FE & YES \\
\hline Species FE & YES \\
\hline
\end{tabular}

$$
\begin{aligned}
& \text { Robust t-statistics in parentheses } \\
& * * * \mathrm{p}<0.01, * * \mathrm{p}<0.05, * \mathrm{p}<0.1
\end{aligned}
$$

\subsection{Parallel trend test}

In order to verify the validity of the baseline model in this paper, a parallel trend test was conducted on the agricultural intermediate consumption of the experimental and control groups, and the following test model was constructed(Equation 3).

Intermediate_consumption $_{\mathrm{i}, \mathrm{t}} \quad=\quad \alpha+\beta_{1}$ post $+\beta_{2}$ time $_{\mathrm{t}-3} *$ Treat $_{\mathrm{i}}+\beta_{3}$ time $_{\mathrm{t}-2} *$ Treat $_{\mathrm{i}}+\beta_{4}$ time $_{\mathrm{t}-1} *$ Treat $_{\mathrm{i}}+\beta_{5}$ current $_{\mathrm{t}} *$ Treat $_{\mathrm{i}}+\beta_{6}$ time $_{\mathrm{t}+1} *$ Treat $_{\mathrm{i}}+\beta_{7}$ time $_{\mathrm{t}+2} *$ Treat $_{\mathrm{i}}+\beta_{8}$ time $_{\mathrm{t}+3} *$ Treat $_{\mathrm{i}}+\beta_{9}$ Chemical_fertilizer $_{\mathrm{i}, \mathrm{t}}+\beta_{10}$ Sown_area $_{\mathrm{i}, \mathrm{t}}+\beta_{11}$ Fuel $_{\mathrm{i}, \mathrm{t}}+\beta_{12}$ Electricity $_{\mathrm{i}, \mathrm{t}}+\beta_{13}$ Film $_{\mathrm{i}, \mathrm{t}}+\beta_{14}$ Pesticide $_{\mathrm{i}, \mathrm{t}}+\beta_{15}$ Mechanization $_{\mathrm{i}, \mathrm{t}}+\beta_{16}$ Wage $_{\mathrm{i}, \mathrm{t}}+\beta_{17}$ gap $_{\mathrm{i}, \mathrm{t}}+\beta_{18}$ Proportion_of_operating_income ${ }_{i, t}+\beta_{19}$ Population_quality $_{\mathrm{i}, \mathrm{t}}+\mu_{\mathrm{t}}+\gamma_{\mathrm{i}}+\varepsilon_{\mathrm{i}, \mathrm{t}}$

Equation 3

where time is an annual dummy variable. The test results are displayed in Table 7 and Fig 2. From the test results, it can be seen that the difference between the experimental and control groups was small and insignificant before the policy was implemented, and after the policy was implemented, the difference between the two groups widened and became significant. Therefore 
the paper uses a double difference model to test that the prerequisites for the common trend hypothesis are met.

Table 7 Parallel trend test results

\begin{tabular}{|c|c|}
\hline VARIABLES & $\begin{array}{l}\text { (Equation 3) } \\
\text { Parallel_trend_test }\end{array}$ \\
\hline post & $\begin{array}{l}0.045 \\
(0.37)\end{array}$ \\
\hline pre_3 & $\begin{array}{l}-0.013 \\
(-0.66)\end{array}$ \\
\hline pre_2 & $\begin{array}{l}0.001 \\
(0.04)\end{array}$ \\
\hline pre_1 & $\begin{array}{l}0.037 \\
(1.10)\end{array}$ \\
\hline current & $\begin{array}{l}0.048 \\
(1.01)\end{array}$ \\
\hline post_1 & $\begin{array}{l}0.104 * \\
(1.97)\end{array}$ \\
\hline post_2 & $\begin{array}{l}0.228 * * * \\
(2.85)\end{array}$ \\
\hline post_3 & $\begin{array}{l}0.222 * * * \\
(2.87)\end{array}$ \\
\hline Constant & $\begin{array}{l}0.523 \\
(0.23)\end{array}$ \\
\hline Observations & 216 \\
\hline Number of Province & 27 \\
\hline R-squared & 0.697 \\
\hline Control & YES \\
\hline Province FE & YES \\
\hline Year FE & YES \\
\hline
\end{tabular}

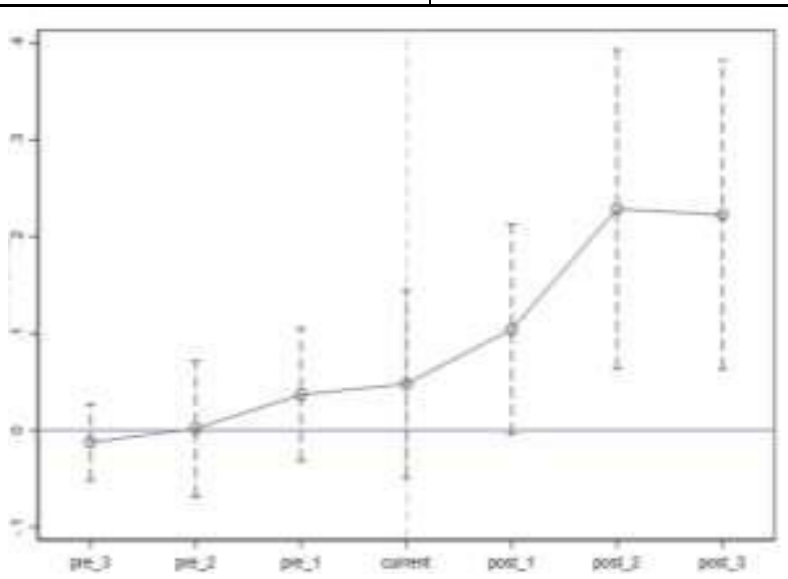

Fig. 2: Policy dynamic effects

\subsection{Robustness tests}

To test the veracity of the effect of the Policy variable on agricultural intermediate consumption, this paper lets the policy shocks to a particular region become random and then makes this random process repeat 1000 times, such a random treatment ensures that the policy reform does not have an effect on intermediate consumption in the responding region, extracts the regression coefficients with standard errors obtained each time, and calculates the corresponding t-values. Figure 3 illustrates the distribution of the estimated $1000 \mathrm{t}$-values, which are indeed concentrated around 0 , consistent with a normal distribution, so that unobserved regional characteristics have essentially no effect on the estimation results.

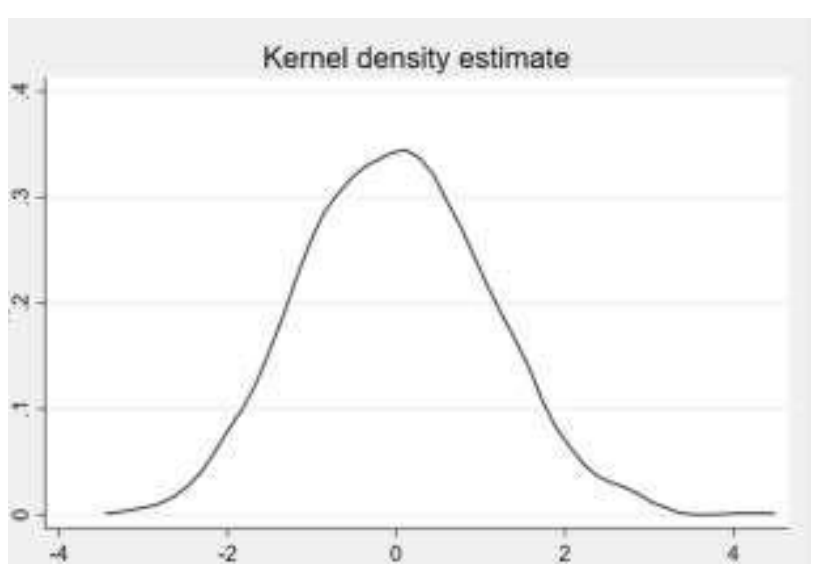

Fig. 3: Placebo test

\section{CONCLUSION}

5.1 Analysis of mechanisms

First, the supply and demand situation of China's fertilizer industry has changed. 2015, after the implementation of a series of policies in the fertilizer industry, fertilizer production capacity fell rapidly, and in 2017 basically reached a balance between supply and demand, but since 2018 production capacity has been lower than demand (Fig. 4), but from the total demand, farmers' fertilizer habits have not changed too much, so farmers do not use fertilizer scientifically, the fertilizer industry demand exceeds supply situation is also the cost of fertilizer This is why the cost of fertiliser has increased. 


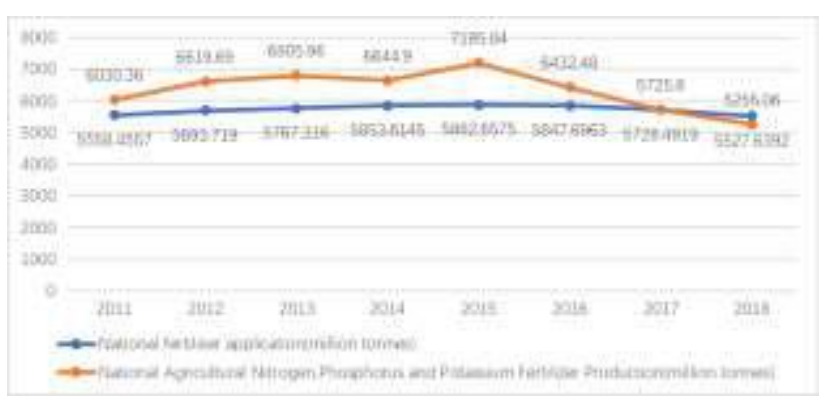

Fig.4 Supply and demand in China's fertilizer industry(Data source: China Statistical Yearbook, China Rural Statistical Yearbook)

Secondly, there is a shift of cost burden. Firstly, VAT is ring-fenced and accumulated at every level. As farmers are at the end of the industrial chain, most individual farmers are unable to offset their taxes through invoices, and the bargaining power of agriculture is weak and the added value of agricultural products is low, so at least part of the increased tax burden was passed on to farmers; secondly, after 2015, the increased costs due to the cancellation of various subsidies were at least partially transferred to farmers, as can be seen from Fig. 5 , Fig. 6 shows that the main business profit margin and assetliability ratio of enterprises in the fertiliser wholesale industry above the limit have remained relatively stable before and after the reform, without any significant fluctuations, reflecting from the side that enterprises have transferred the rising costs to the downstream.

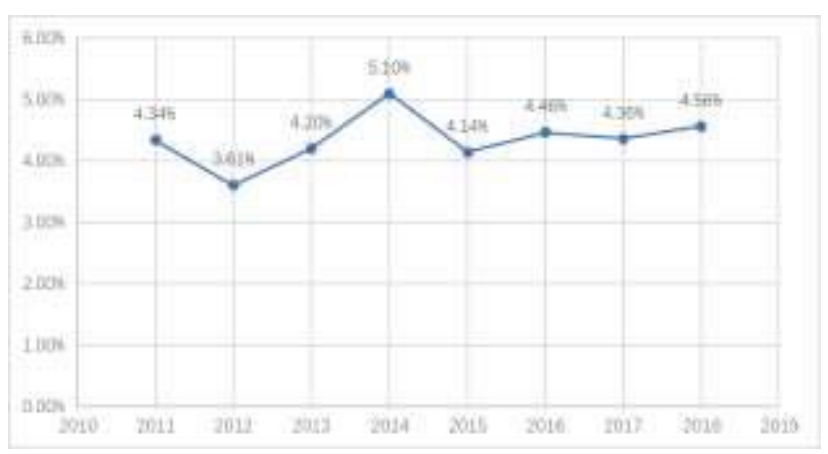

Fig. 5: Profit margin from main business of enterprises in the wholesale fertiliser industry above the limit (Data source: China Trade and Foreign Economic Statistics Yearbook)

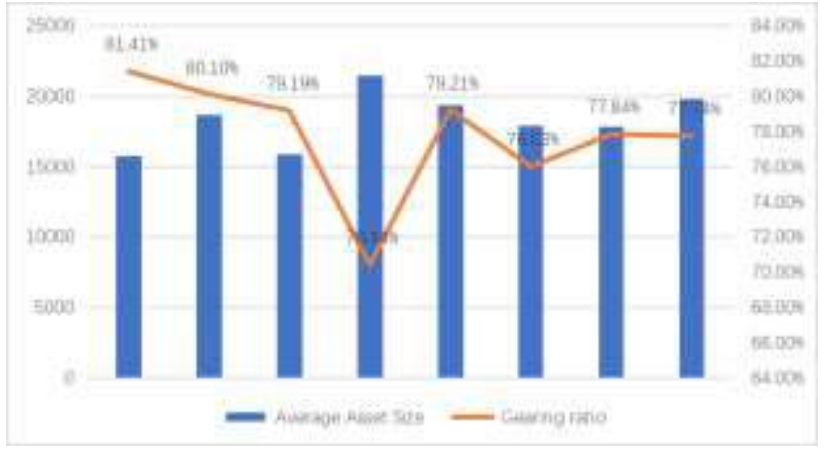

Fig. 6: Average asset size and gearing of enterprises in the fertiliser wholesale industry above the limit (Data source: China Trade and Foreign Economic Statistics Yearbook)

\subsection{Policy Insights}

First, China has long implemented preferential fiscal policies for the production, distribution and application of fertilisers. After years of development, China's fertiliser industry as a whole has shifted from under-capacity to over-capacity. The rise and fall of the fertiliser industry is a matter of food security. In recent years, while the fertiliser industry as a whole has continued to remove the relevant fiscal concessions, it should also be noted that after years of de-capacity in the fertiliser industry, the supply and demand for fertilisers has changed again, and therefore, while eliminating backward production capacity, quality production capacity should also be encouraged, i.e. the government is required to formulate corresponding policies to encourage and guide enterprises to innovate and thus achieve the transformation and upgrading of fertiliser enterprises. The reintroduction of VAT will inevitably lead to enterprises giving up some of their benefits and bearing part of the VAT burden themselves, which can then be considered in other taxes to compensate for the transition. For example, the corporate income tax will provide tax credits for innovative expenditures such as research and development of new types of fertilisers and innovative fertiliser production processes by fertiliser enterprises, so as to stimulate them to break away from the path dependence of the traditional fertiliser industry and innovate excellent fertilisers suitable for the actual soil in China.

Secondly, in general, the government hopes to achieve a gradual reduction in the application of chemical fertilizers while ensuring food security. This requires the active guidance of long-term and short-term fertiliser subsidy policies. In the short term, to achieve zero growth in fertiliser application and to encourage the use of organic fertilisers, a combination of encouragement and 
guidance from the central government, and specific operations by local governments in accordance with local conditions, is needed. Farmers' demand for fertilisers has not changed much due to habits and other reasons, but fertiliser production has begun to fall with the reintroduction of VAT, and changes in supply and demand, coupled with farmers bearing part of the tax burden, have necessitated appropriate government subsidies. As there are local differences in the types and demand for fertilisers, this requires the central government to co-ordinate the planning of fertiliserrelated funds and local subsidies for affected farmers as needed to protect farmers' production incentives and reduce the impact of the structural transformation of fertilisers on farmers. In the long term, in order to achieve ecological civilisation and promote the development of green agriculture, fertiliser application and management needs to be combined with other policy tools. The externalities of agricultural pollution are strong and easily affect soil and water bodies, so it is also necessary for the central government to co-ordinate management and establish long-term special funds to resolutely win the "battle against pollution". This is why the central government should also coordinate and manage the establishment of long-term special funds to win the "battle against pollution". It should also explore the establishment of a dynamic monitoring mechanism for fertilizer-related funds, using modern information management technology and integrating system resources. Comprehensive coverage of all fertilizerrelated funds for comprehensive management.

Third, at present, the input-output ratio of fertiliser use in China is seriously out of balance, the input utilisation rate is low, farmers lack knowledge of fertiliser, resulting in a lack of knowledge of reasonable fertiliser application, the fertiliser industry as a whole is going to capacity and inventory, but farmers apply fertiliser instead of reducing due to factors such as habits, and the relationship between supply and demand is changing again. In order to reduce fertiliser pollution and reduce the impact of the transition period of the fertiliser industry, it is necessary for the state to provide relevant training to farmers to supplement their knowledge of spending and guide them to apply fertiliser in a reasonable manner; to support and set up new agricultural business entities in the form of large planters, large farms or professional co-operatives, etc. to strengthen the degree of specialisation and control the amount of fertiliser applied in a scientific and reasonable manner according to the situation on the ground, so as to reduce the excessive amount produced by the excessive use of fertiliser burden.

\section{REFERENCES}

[1] Bu, Yinglu \& Xing, Y. M.. (2020). Analysis of the impact of agricultural technology extension services on fertilizer use by farmers. Anhui Agronomy Bulletin (17), 94-96. doi:10.16377/j.cnki.issn1007-7731.2020.17.043.

[2] Chen, S. \& Hu, H.. (2017). An empirical study on the impact of different agricultural policies on Chinese farmers' grain production decisions. Agricultural Economics and Management (03), 37-47. doi:CNKI:SUN:NYJG.0.201703-005.

[3] Deng Yijie. (2019). Analysis of the effect of fertilizer application on grain yield in Sichuan Province. Rural Economy and Science and Technology (12), 13+116. doi:CNKI:SUN:NCJI.0.2019-12-010.

[4] Fan, Y. \& Jiang, X.. (2020). The price effect of valueadded tax. Fiscal Studies (09), 105-118. doi:10.19477/j.cnki.11-1077/f.2020.09.009.

[5] Feng, K.. (2016). Preventing VAT reimposition on fertilizers from hurting farmers' interests. Rural Science Experiment (02), 8. doi:CNKI:SUN:NCKX.0.2016-02-005

[6] Huang JK, Chen QG, Wang Qiaojun. (1994). Exploring the reasonable fertilizer application structure and countermeasures in China--an analysis of rice production function model. Agricultural Technology and Economics (05),. doi:CNKI:SUN:NYJS.0.1994-05-010.

[7] Li, Bo \& Wang, Xiaohui. (2019). Research on agricultural fiscal policy issues and countermeasures. Rural Economics $\begin{array}{lll}\text { and } & \text { Technology } & \text { (03), }\end{array}$ doi:CNKI:SUN:NCJI.0.2019-03-049.

[8] Liu, D.W., Li, Q. \& Song, H.H.. (2017). Analysis of fertilizer application efficiency for grain production in China - based on stochastic frontier production function. Resource Development and Marketing (04), 401-407. doi:CNKI:SUN:ZTKB.0.2017-04-004.

[9] Ru, Jingxian. (2008). Analysis of Farmers' Fertilizer Application Behavior and Influencing Factors (Master's thesis, Zhejiang University). https://kns.cnki.net/KCMS/detail/detail.aspx?dbname=CM FD2008\&filename $=2008072577 . \mathrm{nh}$

[10] Shi, Deng-Lin, Wang, Xiao-Li, Duan, Jian-Jun, Liu, AnKai, Luo, An-Huan, Li, Rui-Dong \& Hou, Zai-Fen. (2020). Effect of nitrogen fertilizer reduction with biochar application on organic carbon activity fraction and mineralization in yellow loam rice field soils. Journal of Applied Ecology (12), 4117-4124. doi:10.13287/j.10019332.202012.027.

[11] Wang, Z. L. \& Wang, J. M.. (2011). Analysis of factors influencing price changes in China's fertilizer market: theory and empirical evidence. Price Theory and Practice (05), 51-52. doi:10.19851/j.cnki.cn11-1010/f.2011.05.027.

[12] Wen, T. \& Wang, S. H.. (2012). The impact of fiscal and financial support policies on grain price volatility - An empirical validation based on China 1952-2009. Journal of Southeast University (Philosophy and Social Science Edition) (03), 43-49+127. doi:10.13916/j.cnki.issn1671511x.2012.03.023.

[13] Yang, Lingling. (2018). The effect of fertilizer use on total agricultural output value under econometric modeling--A 
case study of Hefei city. Rural Economy and Technology (08), 156-157. doi:CNKI:SUN:NCJI.0.2018-08-100.

[14] Yang, Xiangdong. (2016). The inspiration of foreign agricultural fiscal policy to China. World Agriculture (01), 92-96. doi:10.13856/j.cn11-1097/s.2016.01.019.

[15] Yin Jun,Dang Jingqi \& Sun Xiaoxia. (2020). Effects of price and substitution effects on fertilizer application in agricultural production: the case of maize and cabbage. Journal of China Agricultural University (05), 209-220. doi:CNKI:SUN:NYDX.0.2020-05-023.

[16] Zhang, H.-L. \& Qin, M.. (2019). Asymmetric transmission analysis of fertilizer prices in China under the perspective of product quality. Price Monthly (07), 9-15. doi:10.14076/j.issn.1006-2025.2019.07.02.

[17] Zhang, W.-X. \& Luan, J.. (2014). An empirical study on the trend of fertilizer price volatility and influencing factors in China. Price Theory and Practice (03), 86-88. doi:10.19851/j.cnki.cn11-1010/f.2014.03.030.

[18] Zhou, K.-Q. \& Yang, Z.. (2019). Fertilizer application and fertilizer-related fiscal tax incentives:A review and outlook. Taxation and Economics (01), 73-78. doi:CNKI:SUN:SWYJ.0.2019-01-012. 